\title{
A Conceptual Model of E-Commerce Taxation Using a Circular Model for E-Commerce Sustainability
}

\author{
Somkeit Noamna and Supaporn Kiattisin* \\ Technology of Information System Management Division, Faculty of Engineering, \\ Mahidol University, Thailand \\ E-mail:somkeit.n@cmu.ac.th; supaporn.kit@mahidol.ac.th \\ ${ }^{*}$ Corresponding Author
}

Received 16 April 2020; Accepted 06 May 2020;

Publication 17 August 2020

\begin{abstract}
E-Commerce tax is among the most crucial factors affecting E-Commerce growth and information and communication technology, including playing a vital role in facilitating the global commerce market. This study aimed to investigate the relationship between ICT development by using the ICT development index (IDI) and E-Commerce diffusion is an effect on E-Commerce taxation principles. The paper was proposed as a new approach and initiatives for implementing E-Commerce development through the circular model for E-Commerce sustainability (CMES). The online questionnaires for the survey were used to gather data via social media, i.e. Facebook, Line and Instagram. The data were gathered from a sample of 308 people who sell products and services through online commerce in Thailand. Exploratory factor analysis (EFA) and confirmatory factor analysis (CFA) were used to validate and measure the construction of the questionnaires. The relationship among the ICT development index, E-Commerce diffusion and the E-Commerce taxation principles was proved to apply successfully to the structural equation modelling (SEM) technique. The results showed that the ICT development index (IDI) has a positive influence on E-Commerce diffusion and E-Commerce taxation principles. Further, the results indicated
\end{abstract}

Journal of Mobile Multimedia, Vol. 16_1-2, 103-130.

doi: 10.13052/jmm1550-4646.16126

(C) 2020 River Publishers 
that E-Commerce diffusion has a positive effect on E-Commerce taxation principles, and hence are significant.

Keywords: E-Commerce taxation principles, E-Commerce diffusion, ICT development index (IDI), structural equation modelling (SEM), circular model for E-Commerce sustainability (CMES).

\section{Introduction}

GDP (Gross domestic product) is a significant national economic growth indicator. The OECD Annual Revenue Statistics 2018 shows that the ratio of national income from taxation per GDP has been increasing in many countries during 2008 and 2009 [1]. In present-day, digital economy is the major policy that has been employed by governments to actuate the domestic economy in many countries all over the world. For instance, the policy is used to improve information technology to be compatible with economic and cultural activities and procedures, especially, E-Commerce stimulation. It can be considered that the digital economy has been a significant source of national income and an essential economic growth indicator since the number of business entrepreneurs who use the online trading platform has been rising continually. Currently, compared to the earlier E-Commerce era the trading aspect and consumer behaviour have been changing considerably due to the expansion of the internet network and information technology [2] including mobile devices which are used nowadays having capabilities to be employed conveniently [3,4]. Not only mobile device users are able to buy and sell products through online platforms easily, but the factors as previously mentioned also influence a large number of businesses that have changed the sales channel from physical stores to be more and more on online shops that emerge as E-Commerce [5].

Moreover, nowadays the E-Commerce system has created efficient supporters such as social media which has connected entrepreneurs with global consumers faster and more conveniently [6]. The statistics of online trading shows that consumer's behaviour worldwide has a tendency to trade via social media such as Facebook and Instagram, which are extensively used worldwide $[7,8,9]$. Due to the switch in business and customer behaviour, the aforementioned causes significant changes in the economic system of many nations because the government's source of income from taxation has been changed [10]. However, E-Commerce taxation in many countries is still not efficient, and as a result not only the taxation does not reach the target but 
also not conform to the nation's economic system that causes the economic decline [11]. In the case of Thailand, from the data of the Fiscal Policy Office year, 2017 reported that 59.4 per cent of the government income was from the revenue department in which the most income was from value-added tax as 29.3 per cent and from corporate income tax as 13.8 per cent, personal income tax as 13.4 per cent and specific tax as 2.2 per cent [12]. Therefore the source of taxation has been different because of the influence of information technology, and this phenomenon will affect taxation in terms of the countries' development, especially, with regards to network infrastructures. Essential digital resources are fundamental for improving the E-Commerce system which is the vital national income source because, in the present-day scenario, trading online needs tools and an intermediate to connect between sellers and buyers. It is considered that the tools and intermediaries are digital resources and digital infrastructure. There are two digital resources in the online trading process: the first is tangible which include the network infrastructure and computer server, and mobile devices and the second is intangible, such as platforms, websites and online trading legalization [13].

One of the essential digital resources is high-speed internet which is able to connect consumers worldwide. Therefore, digital resources and digital infrastructure are influential for the national development of the digital society and trading online. The other essential factors are the conditions that stimulate online trading and government policy involved in improving digital resources [14]. Not only information technology and communication but also efficient utilization of public internet are important factors in enhancing digital resources. These conditions influence the development of the E-Commerce system, which nowadays is the essential national income $[15,16]$.

The improvement of information technology, network system and infrastructures in which affiliate E-Commerce is the vital system and variant in improving and promoting E-Commerce dictates the part of national development. Advocating and developing information technology and digital infrastructures are necessary for the country's development. However, critical methods are economic development and population acknowledgement [17]. These methods are significantly relevant in improving the information technology system and digital communication, and thus they relate dramatically with development and advocating the national E-Commerce system. However, the government needs to plan and administer dynamically to provide adequate digital resources and accomplish reliability for domestic and international entrepreneurs who are able to expand the business and connect and cooperate with others through digital resources conveniently and sustainably. 
According to the identified problem, therefore, we have reached and proposed a new idea and a new model for the E-Commerce taxation legalization and policy for the present-day digital society. Structure equation modelling (SEM) was used to evaluate factors that are relevant in the E-Commerce taxation. The expected result is to help institutions and stakeholders in the E-Commerce taxation legalization and policy to have guidance and methods to legalize appreciably and accurately the E-Commerce taxation based on the E-Commerce taxation principles $[18,19]$.

The rest of the paper consists of five topics: related work, methodology, results, discussion and finding and conclusion. Firstly, the factors that related with E-Commerce taxation are studied. Secondly, the experiments by descriptive and multivariate statistics were used to estimate the model. Thirdly, it is explained that the E-Commerce growth was affected with ICT development within results interpreted. The strong relationship between ICT development and E-Commerce diffusion was reflected in the outputs. Fourthly, the guideline for E-Commerce taxation through a conceptual circular model for E-Commerce sustainability (CMES) is proposed. Lastly, the conclusion described about how to use a new perspective for guiding the policy for E-Commerce taxation.

\section{Related Work}

The concept of this study has been constructed from various literatures and E-Commerce taxation theories, including factors that are relevant to E-Commerce tax. A review of the existing literature includes theories and empirical studies. The analysis has been divided into three parts as detailed hereunder.

\subsection{E-Commerce Taxation Laws}

In the United States of America, all states have been the income source from online trading. This is in consequence of the launching of the law called 'The Internet Tax Freedom Act 1998' for supporting and providing online trading businesses. Later on, there was a legislation to improve the previous law called 'The Permanent Internet Tax Freedom Act 2016' to postpone taxation in the E-Commerce system and to access the internet. The law enforcement has been postponed to June 30th, 2020 and the circumstance benefits domestic customers because the law will burden the customers in paying tax in many ways such as bit tax, bandwidth tax, e-mail tax, etc. [20]. Moreover, under 
the law called 'Diverted Profit Tax Act 2017 (DPT)' which the Australian government enacted to increase the capability of Commission of Taxation, the commission has power in taxation for multinational corporations (MNCs) that avoid paying tax in Australia. The law enforcement is in operation since July 1st, 2017 and the tax rate is 40 per cent. The MNCs that have income worldwide up to 1 billion AUD and income in Australia up to 25 million AUD must pay the tax [21].

There is a new approach to taxation in India called "Equalization Levy'. It is the equalization between the domestic and international entrepreneurs [20]. The tax is for customers at 6 per cent of advertising expenses on the online system or in the other services from the MNCs that have permanent establishment (PE) in the countries of income source and also if the value of the business is more than 100,000 INR. The law states that these MNCs must register in India [1]. It is considered that governments in many countries have been interested in the taxation of E-Commerce system more and more because the aspect of trading has been changing and tending to grow dramatically. David and William [10] studied taxation and proposed the idea that taxation is different in each country, for example, in the United States, every state has an independent taxation policy because of the Federal Republic system. Moreover, Steven [22] enumerates the reasons for the distinctive nature of the E-Commerce system taxation policy because the policy of countries has different obstacles in taxation. The diversity of economic conditions between developed and developing countries is one of the reasons. Richard and Subhajit [11] proposed the idea that the policy which the OECD has been trying to force to authorize the standard of the E-Commerce system taxation is unable to cover every country, especially, developing countries. Due to poverty, therefore, those countries have no financial stability to follow the regulation as in developed countries. Burca [23] has studied and concluded that E-Commerce regional taxation or E-Commerce product and income raking taxation which has been used in many countries cannot be practically feasible because of overlapping in taxation policy. The taxation overlapping causes a higher taxation burden on the entrepreneurs. Some researchers introduced an E-Commerce taxation model that is same as the US model, for example, there should be a third party to moderate E-Commerce business between sellers and customers.

However, the model must have the same standard of instruction and legislation for regular and E-Commerce products to establish fairness in online trading for both domestic and international customers and entrepreneurs [24]. 


\subsection{Adam Smith's Taxation and OECD E-Commerce Taxation Principles}

Adam Smith, the father of economics, wrote a significant book called 'The Wealth of Nations' published in 1776 [25]. The book delivers four essential fundamentals for taxation which are (1) equality, (2) certainty, (3) the convenience of payment and (4) the economy in collection. These fundamentals have been sufficient and acceptable until today. In 1992, the OECD has suggested an E-Commerce taxation model called the 'Taxation Framework Conditions for electronic commerce' [18] which has five principles. However, Rifat [19] had studied and suggested that the framework should be considered as a guideline for the E-Commerce taxation. The framework is as follows:

(1) Neutrality: Taxation should apply to be neutral and equitable between forms of online commerce and conventional forms of business.

(2) Efficiency: Compliance rates for administrative expenses and taxpayers for the tax authorities should be reduced as far as feasible.

(3) Certainty and simplicity: Clearance and straightforwardness in tax rules to understand are necessary to taxpayers. Thus, taxpayers can estimate the tax results in advance of a transaction, including knowing when, where and how the tax is to be accounted for.

(4) Effectiveness and fairness: Tax evasion must be minimized while keeping counter-acting measures proportionate to the risks involved. Taxation should collect in the right time and the right among.

(5) Flexibility: Flexible and dynamic in taxation policy to ensure that the approach keeps along with commercial developments and technological aspects.

Government taxation for a citizen is most important for the national income and the citizen has to pay tax for national development, for example, tax could be spent in social welfare measures and hence promote valuable policies sufficiently and efficiently. The government must have applicable taxation policy which suits national conditions such as a taxpayer's income. One of the most important issues in taxation is the balance of spending the tax on infrastructure investment and improving the public utility system which is necessary for economic growth. For stability in national taxation, not only the taxation must follow the fundamental of efficient taxation but also agreeable and suitable with the national economic conditions [26]. 


\subsection{Digital Resources and E-Commerce}

Online trading nowadays needs tools and an intermediary to connect and communicate between sellers and buyers [15]. The devices are considered as digital resources or digital infrastructures. There are two categories of digital resources in online trading: firstly, tangible, such as infrastructures, internet networks, personal computers, mobile devices, etc. and secondly, intangible, such as platforms or websites and legislations in online trading [27]. A digital resource is fundamental for communication and connection, for example, high-speed internet is one of the essential resources to connect online buyers and sellers worldwide [28]. Currently, 5G technology is the new communication technology that is integrated into many countries across the world to show the connection and communication technology readiness. In conclusion, digital resources and digital infrastructures are noticeably essential for promoting and developing the country in term of digital society and online trading. Jennifer et al. [14] studied and suggested that conditions and policies which are involved in developing digital resources are remarkable in the E-Commerce system development process in both C2C and B2C types. The researchers collected data from 10 countries (Singapore, Taiwan, Brazil, China, Denmark, Japan, France, Germany, United States and Mexico) demonstrated that there are three main factors involved in broadening the E-Commerce system as discussed hereunder:

(1) Global environment: MNC strategies, global production networks, global competition and trade liberalization.

(2) National environment: information infrastructure, industry infrastructure and competition, economic and financial resources, organizational environments, consumer preferences and demographics.

(3) National policy: E-Commerce promotion, telecom liberalization and ECommerce legislation.

Kevin [15] and Mahdi [16] studied and suggested that adequate information and communication system, including an efficient internet network, will support economic development. Moreover, when countries are accessible with these factors, it will benefit the E-Commerce development which is the modern trading aspect and an important national income source. Therefore, the development of information and communication systems and E-Commerce public utility are the significant mechanist and variable in developing and promoting the E-Commerce system. Anteneh [17] suggests that not only supporting and emerging information technology and digital 
infrastructure is very important for a country's development but also economical and education improvement. Anteneh has shown the main factors which conform to the ICT development index of ITU [29], and this identification is an international assessment of information technology and communication system development that includes (1) ICT access, (2) ICT use, and (3) ICT skill [30, 31, 32, 33, 34].

Thus, information technology development always relates to a nation's development and also promoting the E-Commerce system. However, the government needs to plan and manage information technology and digital resources adequately and render them trustworthy to help people and entrepreneurs of both domestic and international origin so as to equip them develop their business to connect and cooperate by using digital resources conveniently and sustainably.

From the study and reviews of literature related to E-Commerce taxation, it can be seen that there are many factors related to E-Commerce taxation. The E-Commerce taxation should follow the OECD taxation guidelines and has to be consistent with Adam Smith's taxation principles. However, the factor that enhances E-Commerce business growth is digital resources such as information and communication technologies and infrastructures for E-Commerce. Importantly, E-Commerce tax policies must support and be of convenience for online businesses thereby ensuring flexibility for E-Commerce diffusion.

\section{Methodology}

The descriptive and multivariate statistics were used to test the model in this study. In a finding with regard to the relationship through review of literature, three factors (E-Commerce taxation principles, ICT development index and E-Commerce diffusion) were studied. Figure 1 depicts the research processes and the details described as follows.

\subsection{Conceptual Model and Hypotheses}

The conceptual model of this research is based on the relate studies, the conceptual model and hypotheses being developed as shown in Figure 2, Figure 3 by three components, respectively.

1. ICT development index (IDI)

The approach to the ICT development index consists of three factors:

ICT access, ICT use and ICT skill [30, 31, 32, 33, 34]. 


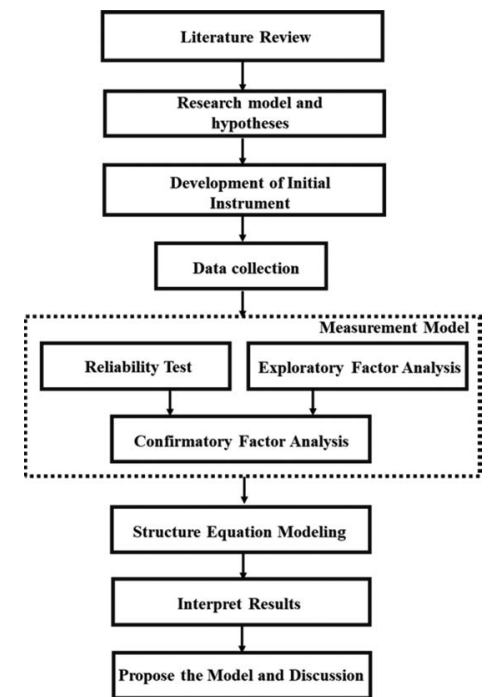

Figure 1 Research processes.

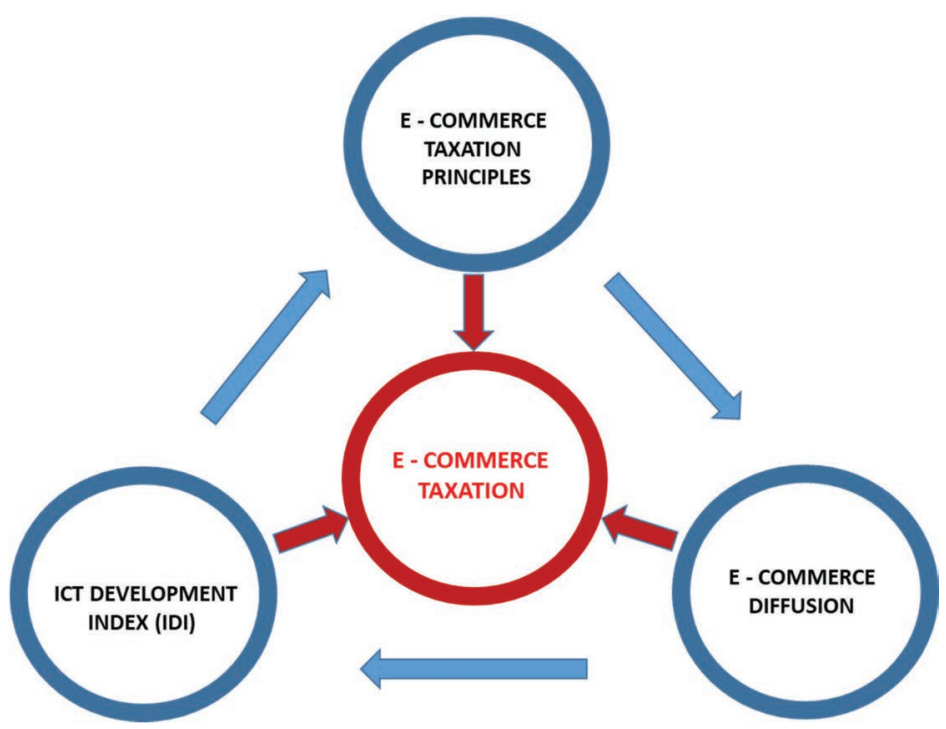

Figure 2 Conceptual model. 


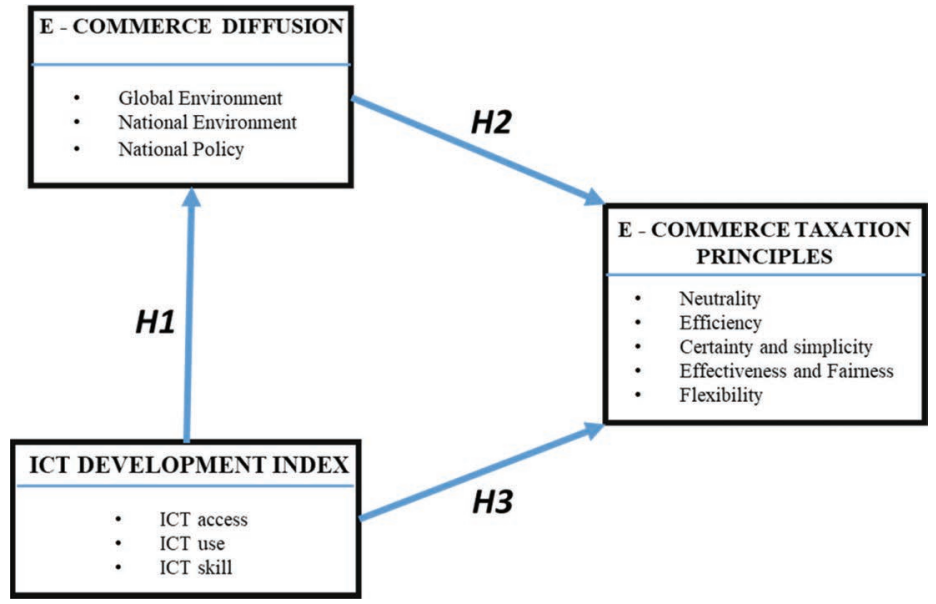

Figure 3 Hypotheses model.

H1: ICT development index is positively associated with E-Commerce diffusion.

2. E-Commerce diffusion

The global environment and national policy that concern E-Commerce diffusion consists of three factors: global environment, national environment and national policy [14].

H2: E-Commerce diffusion is positively associated with E-Commerce taxation principles.

3. E-Commerce taxation principles.

The principles of E-Commerce taxation consist of five factors: neutrality, efficiency, certainty and simplicity, effectiveness and fairness and flexibility $[18,19]$.

H3: ICT development index is positively associated with E-Commerce taxation principles.

\subsection{Development of Initial Instrument}

\subsubsection{Development Questionnaires for Survey}

Questionnaires were used to collect 46 items that relate to E-Commerce taxation for the research. This way, the survey has six parts as detailed hereunder.

Part 1: 4 questionnaires about the general information of the respondents. Part 2: 3 questionnaires about buying-selling behaviour in products and services on the internet. 
Part 3: 10 questionnaires about the principles of E-Commerce taxation principles.

Part 4: 11 questionnaire about the development of information and communication technology (based on ICT development index, IDI) relevant to E-Commerce.

Part 5: 18 questionnaire about factors that are relevant to E-Commerce diffusion.

Part 6: The additional comments from the research participants.

\subsubsection{Content validity of the instrument}

The questionnaire was approved by the thesis advisor and three experts who have tax expertise, economic and information technology in electronic commerce to check content's validity and language. The criteria for evaluating all questionnaires with the contents or purposes for measurement is appropriate for the research by considering the IOC value more than 0.5 [15] in each question and improve the questions according to the recommendations. The IRB (the Institutional Review Board of Mahidol University) has approved the questionnaire via No. CIRB 2019/248.2409.

\subsubsection{Refinement of the items and development of final instruments}

The questionnaire that passed the content validation was sent in google form to the 30 respondents for trying out samplings with the online sellers [15, $35,47]$. The reliability test resulted from the 46 items on the factors in E-Commerce taxation calculated with the program SPSS V.24 through the Cronbach's Alpha-based reliability test contributed to the acceptable value of more than 0.70 [41] at 0.877 .

\subsection{Data Collection}

In determining the sample size, the researcher defined two criteria with Hair [41] and Cochran's formula [46]. Based on these two criteria, the researcher was assigned 400 samples and given 5\% to drop out. To obtain the result of sampling in this experiment, at least 380 sample sizes were taken into confidence in the analysis of this study [41]. The questionnaires were sent as private messages in google form via social media such as Facebook, Line and Instagram to a sample group. 


\subsection{Descriptive Statics and Measurement Model}

This research is a quantitative and survey study. The primary assessments were made using AMOS version 22 and SPSS version 24 for descriptive test and construct validity analysis. The exploratory factor analysis (EFA) and confirmatory factor analysis (CFA) were used to define item validities as well as identify and confirm influential factors. The construct validity measured the convergent validity and discriminant validity for all the constructs in the model [41, 42, 43, 44]. We confirmed the consistency of the model with empirical data by considering the Chi-Square value $\left(\chi^{2}\right)$, Goodness of Fit Index (GFI), Tucker Lewis Index (TLI), Normal Fit Index (NFI), Comparative Fit Index (CFI) and P-Value [45].

\subsection{Structure Equation Modelling}

The structural equation modelling explains the relationship between a construct (latent) and a variable. The processes consist of five steps to develop the structural model to explain the relationship among variables: model specification, model identification, model estimate, model evaluation and model modification $[44,45]$. The program SPSS AMOS version 22 was used to explore the relationship among the whole constructs by the path diagram.

\subsection{Proposed Model and Discussion}

The model is presented with all relevant factors in E-Commerce taxation with digital resources consumption. The discussion will interpret our results based on theories and give recommendations that concern E-Commerce taxation.

\section{Results}

This section elaborates our results with reference to sample and procedure, measures, exploratory factor (EFA) analysis, confirm factor analysis (CFA), descriptive statistics, path analysis in structure equation modelling and concept of a circular model for E-Commerce sustainability (CMES).

\subsection{Sample and Procedure}

The questionnaires were sent as private messages on social media such as Facebook, Line and Instagram to a sample group one by one to make sure they are the right target for this study. The 308 respondents included $72 \%$ of 
females and $28 \%$ males. The demographic profiles represented the following data. More than $67 \%$ of them graduated with a bachelor's degree, $29 \%$ had higher than a bachelor's degree and $0.04 \%$ were under bachelor's degree. With reference to frequency for doing business via online, the statistics showed quite similar for 1-2 weeks and 3-4 weeks, at 39\% and 30\%, respectively. The same has been 11\% for 5-6 weeks and for than more than 6 weeks it is $20 \%$. The proportion for usage time on online shopping mostly is $1-2$ times (58\%), also 3-4 times (20\%), less than 30 minutes is $15 \%$ and $7 \%$ for more than 7 times.

\subsection{Descriptive Statistic Measures}

The descriptive statistics were mainly used in measuring items in order to clarify the overall values of estimations from the respondents. For the value of means between 3.48 and 4.26, the Standard Deviations (S.D.) were 0.68 to 0.96 . Table 1 depicts the statistics that the total question items passed the value loading criteria being rejected by the assessment. E-Commerce taxation principles $[15,19]$ consists of five dimensions which comprise of efficiency, neutrality, effectiveness and fairness, certainty and simplicity and flexibility. The Cronbach's alpha for each of the five dimensions ranged from 0.71 to 0.94. ICT development was measured using the ICT development index that consists of three dimensions which are ICT access, ICT use and ICT skill [15, 19, 30, 31, 32, 33]. The Cronbach's alpha for each ICT development index ranged from 0.82 to 0.85 for total dimensions. The E-Commerce diffusion was examined by the key global, environment and policy factors that act as determinants for E-Commerce diffusion by centre for research on information technology and organizations (CRITO) framework [14]. The dimension consists of three measurements which comprise of global environment, national environment and national policy. Further, the Cronbach's alpha for these dimensions ranged between 0.87 and 0.92 .

\subsection{Exploratory Factor Analysis and Confirm Factor Analysis}

EFA was evaluated using SPSS version 24. In the EFA method, the KaiserMeyer-Olkin (KMO) and Barlett test determined whether data is appropriate for the EFA. KMO coefficient was found to be 0.866, and Barlett test was significant $\left(\chi^{2}=9946.890 ; \mathrm{p}=0.001\right)$. These outputs presented that the sample is large and sufficient to conduct the EFA $[8,35,36]$. The results of factor analysis with mean, SD, reliability values and communities are given in 
Table 1 Descriptive statistics and EFA results of E-commerce taxation principles, ICT development index, and E-commerce diffusion

\begin{tabular}{|c|c|c|c|c|}
\hline Factor name and statements & Mean & SD & $\begin{array}{c}\text { Reliability } \\
(>0.7)\end{array}$ & $\begin{array}{c}\text { Communities } \\
(>0.5)\end{array}$ \\
\hline \multicolumn{5}{|c|}{ E-Commerce taxation principles } \\
\hline NT1 & 3.48 & 0.911 & 0.701 & 0.720 \\
\hline NT2 & 3.59 & 0.863 & 0.701 & 0.645 \\
\hline $\mathrm{EC} 1$ & 3.89 & 0.898 & 0.716 & 0.760 \\
\hline $\mathrm{EC} 2$ & 3.83 & 0.938 & 0.716 & 0.721 \\
\hline CS1 & 4.24 & 0.844 & 0.948 & 0.883 \\
\hline $\mathrm{CS} 2$ & 4.22 & 0.879 & 0.948 & 0.874 \\
\hline EF1 & 3.95 & 0.793 & 0.740 & 0.754 \\
\hline $\mathrm{EF} 2$ & 3.58 & 0.963 & 0.740 & 0.743 \\
\hline FT1 & 3.80 & 0.955 & 0.932 & 0.820 \\
\hline FT2 & 3.77 & 0.954 & 0.932 & 0.874 \\
\hline \multicolumn{5}{|l|}{ ICT development index } \\
\hline IA1 & 3.85 & 0.891 & 0.822 & 0.835 \\
\hline IA2 & 4.19 & 0.681 & 0.822 & 0.769 \\
\hline IA3 & 4.18 & 0.774 & 0.822 & 0.752 \\
\hline IA4 & 3.78 & 0.861 & 0.822 & 0.671 \\
\hline IA5 & 4.15 & 0.845 & 0.822 & 0.692 \\
\hline IU1 & 4.26 & 0.694 & 0.826 & 0.757 \\
\hline IU2 & 4.03 & 0.790 & 0.826 & 0.787 \\
\hline IU3 & 4.14 & 0.726 & 0.826 & 0.708 \\
\hline IS1 & 3.88 & 0.770 & 0.855 & 0.655 \\
\hline IS2 & 3.77 & 0.797 & 0.855 & 0.809 \\
\hline IS3 & 3.87 & 0.821 & 0.855 & 0.757 \\
\hline E-Commerce diffusion GE1 & 4.06 & 0.815 & 0.879 & 0.588 \\
\hline GE2 & 3.92 & 0.717 & 0.879 & 0.709 \\
\hline GE3 & 4.02 & 0.742 & 0.879 & 0.679 \\
\hline GE4 & 3.95 & 0.790 & 0.879 & 0.775 \\
\hline GE5 & 4.07 & 0.720 & 0.879 & 0.747 \\
\hline GE6 & 4.06 & 0.710 & 0.879 & 0.768 \\
\hline NE1 & 3.85 & 0.836 & 0.911 & 0.774 \\
\hline NE2 & 3.82 & 0.811 & 0.911 & 0.750 \\
\hline NE3 & 3.88 & 0.828 & 0.911 & 0.729 \\
\hline NE4 & 3.82 & 0.827 & 0.911 & 0.716 \\
\hline NE5 & 3.95 & 0.812 & 0.911 & 0.711 \\
\hline NE6 & 3.59 & 0.836 & 0.911 & 0.788 \\
\hline NE7 & 3.93 & 0.734 & 0.911 & 0.597 \\
\hline NE8 & 3.78 & 0.814 & 0.911 & 0.677 \\
\hline NE9 & 4.10 & 0.776 & 0.911 & 0.597 \\
\hline NP1 & 3.98 & 0.805 & 0.922 & 0.701 \\
\hline NP2 & 3.98 & 0.829 & 0.922 & 0.813 \\
\hline NP3 & 4.05 & 0.849 & 0.922 & 0.807 \\
\hline
\end{tabular}

Notes: $\mathrm{KMO}=0.866($ Ref. $>0.7) ;$ Chi-square $=9946.890 ; p=0.000$ 
Table 2 CFA results for E-commerce taxation principles, ICT development index and E-commerce diffusion

\begin{tabular}{lcccccccc}
\hline $\begin{array}{l}\text { Variable } \\
(\mathrm{N}=308)\end{array}$ & df & $\chi^{2}$ & $\begin{array}{c}\chi^{2} / \mathrm{df} \\
(<2)\end{array}$ & $\begin{array}{c}\text { CFI } \\
(>0.95)\end{array}$ & $\begin{array}{c}\text { NFI } \\
(>0.95)\end{array}$ & $\begin{array}{c}\text { GFI } \\
(>0.95)\end{array}$ & $\begin{array}{c}\text { RMSEA } \\
(<0.05)\end{array}$ & $\begin{array}{c}\mathrm{P} \\
(>0.05)\end{array}$ \\
\hline $\begin{array}{l}\text { E-Commerce taxation } \\
\text { principles }\end{array}$ & 23 & 32.98 & 1.43 & 0.99 & 0.98 & 0.97 & 0.038 & 0.081 \\
$\begin{array}{l}\text { ICT development index } \\
\text { E-Commerce diffusion }\end{array}$ & 24 & 31.36 & 1.30 & 0.99 & 0.98 & 0.98 & 0.030 & 0.143 \\
\hline
\end{tabular}

Table 1. The CFA model was used to prove the factors within the constructs of a set in the observed variable. The CFA outputs depicted in Table 2 depicts the fit indices for E-Commerce taxation principles, ICT development index and E-Commerce diffusion, and were fit within the modified values as Browne suggested $[40,41]$.

\subsection{The Measurement Model}

The data collected from 39 questionnaires regarding factors affecting ECommerce taxation are presented in Tables 3 and 4. In Table 3, estimation of the internal consistency computed from the composite reliability (CR) with sufficient values more than 0.70 was in the range $0.80-0.98$ [41]. In addition, the evaluation of the convergent validity calculated from the average variance extracted (AVE) was acceptable if the values were more than 0.50 [41] at 0.50-0.95. Furthermore, CR is higher than AVE for all constructs. Therefore, our results show that the factors in the measurement model have adequate convergent validity [42]. Estimating the discriminant validity was to expose the constructs in the model that could hence indicate the specific composite validity by the AVE value. The square root of the average variance extracted (AVE) was more than the correlations as shown in Table 4. This verifies the non-existence of multi-collinearity and discriminant validity for testing of the whole constructs.[43].

Table 3 Construct reliability and validity

\begin{tabular}{lcccc}
\hline Constructs & $\begin{array}{c}\text { Item } \\
\text { Code }\end{array}$ & $\begin{array}{c}\text { Cronbach's Alpha } \\
(>0.70)\end{array}$ & $\begin{array}{c}\text { Composite } \\
\text { Reliability } \\
(>0.70)\end{array}$ & $\begin{array}{c}\text { Average Variance } \\
\text { Extracted } \\
(>0.50)\end{array}$ \\
$\begin{array}{l}\text { E-Commerce Taxation } \\
\begin{array}{l}\text { Principles } \\
\text { ICT Development Index }\end{array}\end{array}$ & ETP & 0.86 & 0.80 & 0.50 \\
E-Commerce Diffusion & ED & 0.90 & 0.80 & 0.58 \\
\hline
\end{tabular}


Table 4 Correlations, square root of average variance extracted (AVE), means and standard deviations

\begin{tabular}{lccc}
\hline Constructs & ETP & IDI & ED \\
\hline E-Commerce Taxation Principles & $(0.70)$ & & \\
ICT Development Index & $0.50^{* *}$ & $(0.76)$ & \\
E-Commerce Diffusion & $0.54^{* *}$ & $0.66^{* *}$ & $(0.97)$ \\
\hline \multicolumn{1}{c}{ Mean } & 3.83 & 4.01 & 3.93 \\
SD & 0.60 & 0.55 & 0.56 \\
\hline
\end{tabular}

Notes: ${ }^{* *}$ Correlation is significant at the 0.01 level (two-tailed). The square root of average variances (AVE) are showed in diagonal brackets.

\subsection{Structure Equation Modelling}

All hypotheses were proved of the relationship by structure equation modelling. As stated, H1: claims that ICT development index is positively related to E-commerce diffusion, H3: ICT development index is positively related to the E-Commerce taxation principles and $\mathrm{H} 2$ : E-Commerce diffusion is positively associated with the E-Commerce taxation principles. Figure 4 illustrates the measurement of the SEM for the research model.

The model was tested using the good of fitness fit analysis. Several indices for the evaluated final model depict the following results: $\chi^{2}=46.99$, $\mathrm{df}=33, \chi^{2} / \mathrm{df}=1.42$, comparative fit index $(\mathrm{CFI})=0.991$, normed fit index $(\mathrm{NFI})=0.972$, goodness-of-fit index $(\mathrm{GFI})=0.973$ and root mean square error of approximation (RMSEA) $=0.037$. Following the results, the report confirmed that the research model is acceptable and appropriate to the data by using the test of goodness of fit of the model [45]. Considering the estimation of factor loading in the SEM model, the highest value of the observed variable in E-Commerce taxation principles was effectiveness and fairness $(\beta=0.77)$. The highest score of the observed variable in $\mathrm{E}$ Commerce diffusion was the global environment $(\beta=1.13)$. In the observed variable of the ICT development index (IDI), the highest value was ICT use ( $\beta=0.85$ ). Table 5 represents the regression weights for the relation between the variables. Total constructs are positive and significant $(\mathrm{p}<0.001)$. The first assessment between the ICT development index and E-Commerce diffusion showed a positive relationship $(\beta=0.63, \mathrm{p}=0.000)$. The second assessment, which is between the E-Commerce diffusion is positively related to the E-Commerce taxation principles $(\beta=0.28, \mathrm{p}=0.000)$. In part, the ICT development index (IDI) is positively related to the E-Commerce taxation principles $(\beta=0.48, \mathrm{p}=0.000)$. The squared multiple correlations $\left(R^{2}\right)$ for the E-Commerce diffusion were 0.40 , and for tax principles it was 


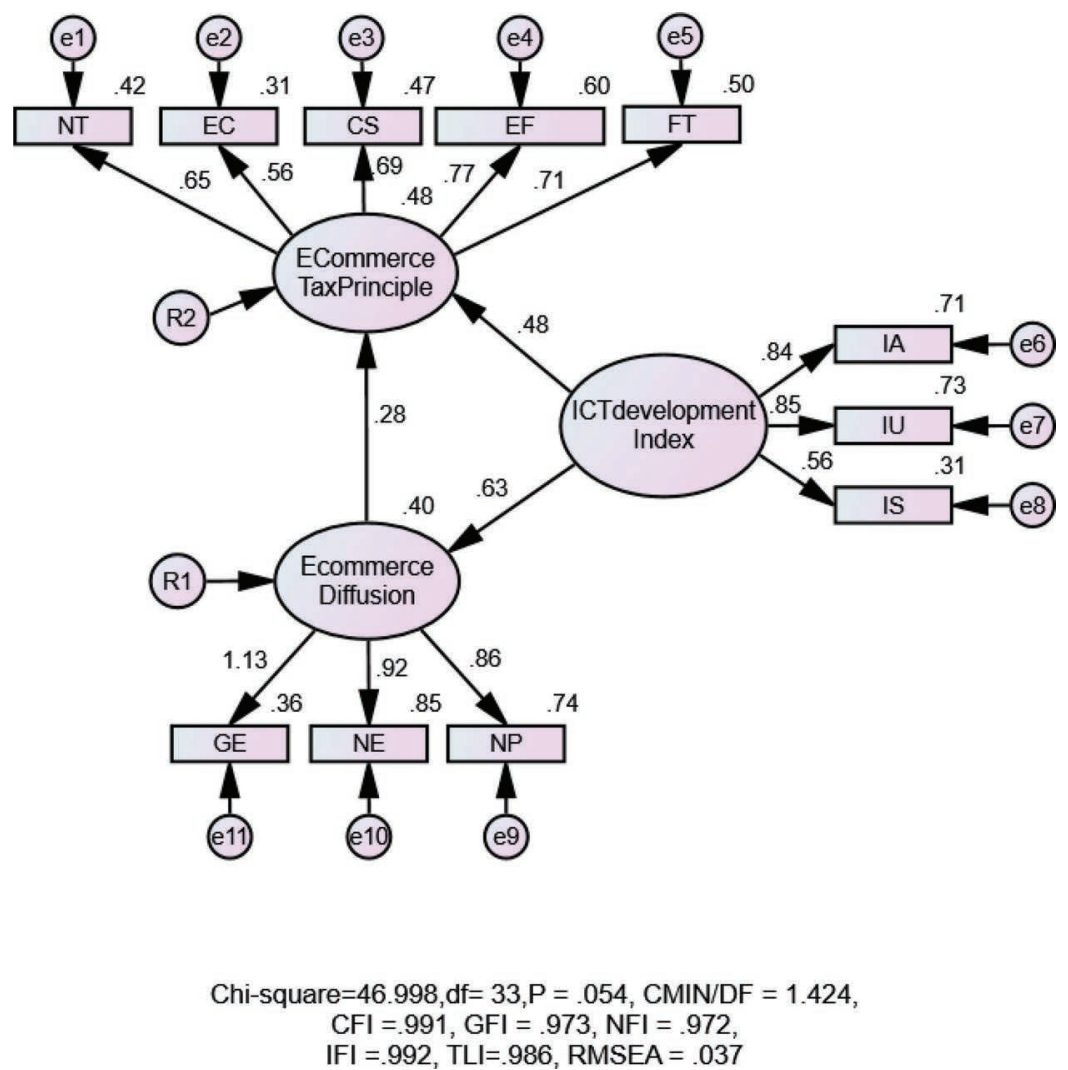

Figure 4 The structural model of the study with standard estimation coefficients.

0.48 . This indicates that $40 \%$ of the E-commerce diffusion was represented by the ICT development index (IDI) of $40 \%$ and $48 \%$ of the E-Commerce taxation principles represented with the E-commerce diffusion and the ICT development index (IDI) in the model. The $\beta$-value of 0.64 indicates that the relationship is strong. This means that ICT development index (IDI) is important in determining the E-Commerce diffusion.

\subsection{Circular Model for E-Commerce Sustainability (CMES)}

In this part, the total factors are combined into the circular model for E-Commerce sustainability (CMES). As shown in Figure 5, the proposed model consists of three categories as detailed hereunder. 


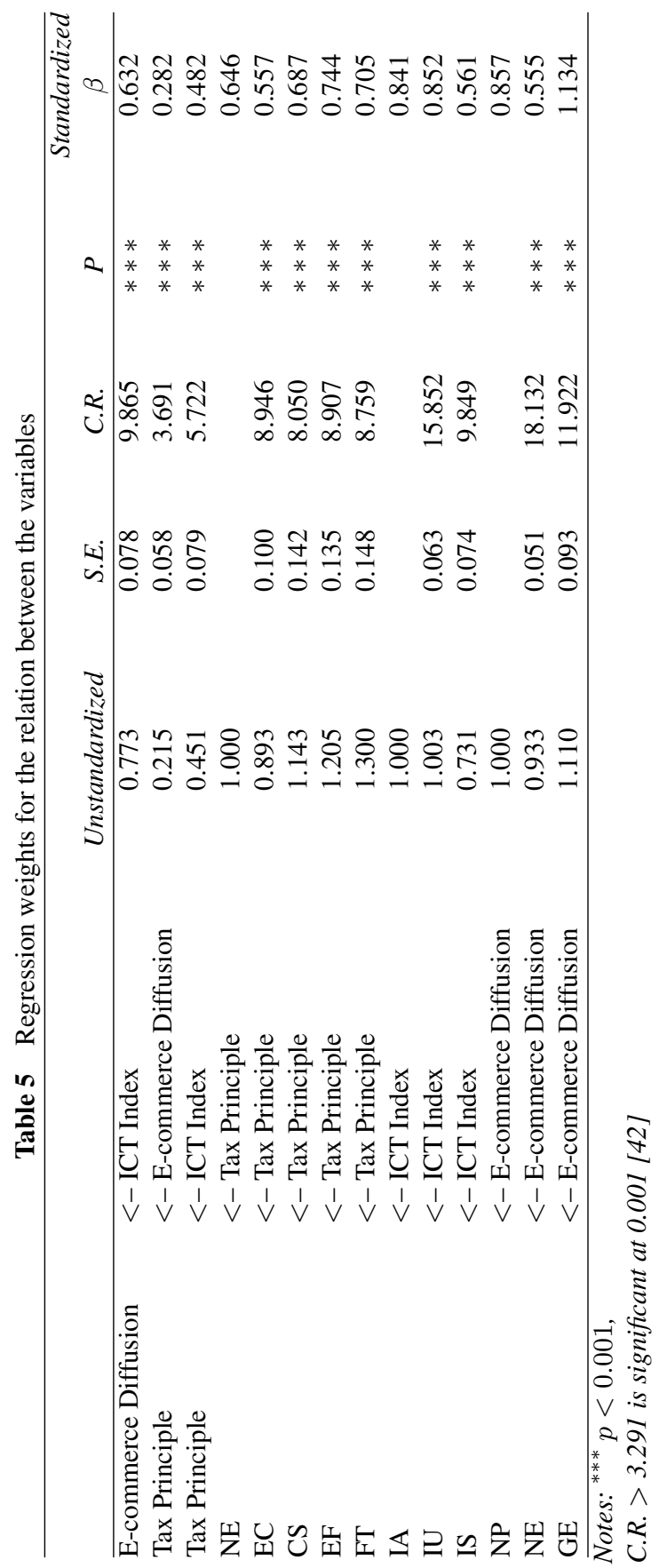




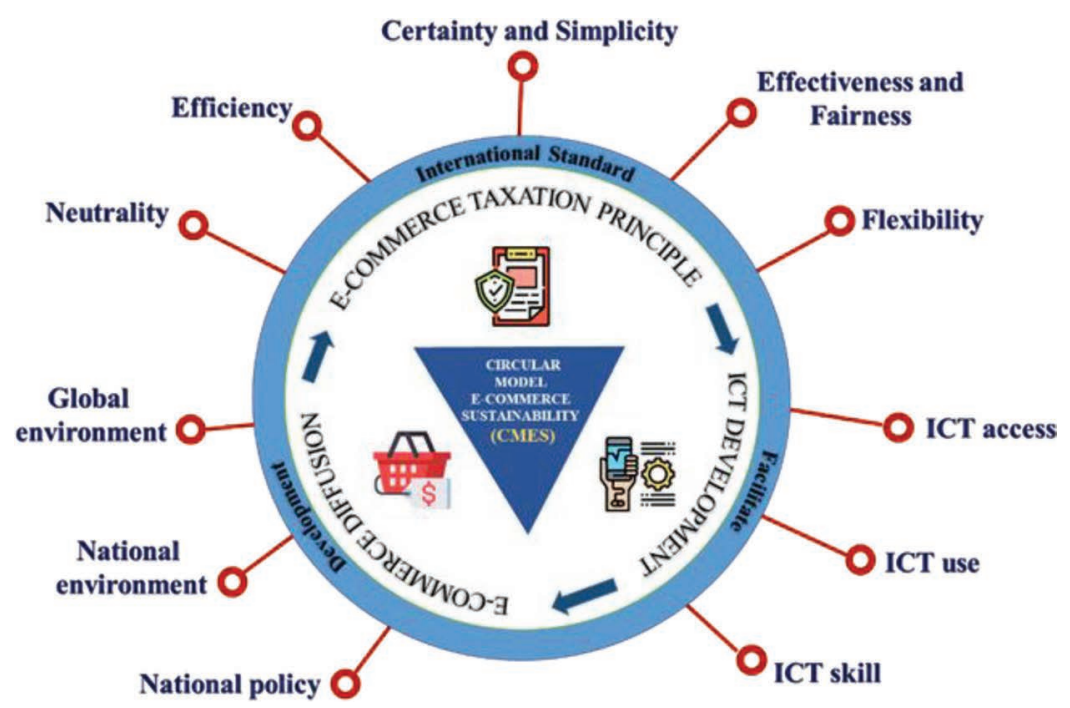

Figure 5 Circular model for E-Commerce sustainability (CMES).

\subsubsection{E-commerce taxation principles}

The E-Commerce taxation principles consist of five topics. Taxation should seek to be neutral and equitable between forms of online commerce and between conventional businesses. The costs for taxpayers and administrative expenses for the tax authorities should be minimized based on the efficiency principle. Certainty and simplicity in the tax regulations should be clear and frank to savvy so that taxpayers can plan the tax consequences in advance in the transaction and how the tax is to be accounted for. The policy for taxation should the right amount of tax and at the right time. The hidden factors for tax evasion and avoidance must be minimized by the principles of effectiveness and fairness.

The flexibility in the systems for taxation should be dextrous and dynamic to ensure that the online businesses keep pace with new technologies and modern commercial developments. These principles should be based on international policy standard. The policies and regulations of E-commerce should remain consistent with this approach.

\subsubsection{Information and communication technology development}

Information and communication technology are essential as they also facilitate E-Commerce growth. Many countries that have an investment in high ICTs will benefit from increased productivity effected by E-Commerce. 
Therefore, the ICT development index (IDI) is designed to be global and reflect changes taking place in countries at different levels of ICT development. It is comprised of 3 subindices and 11 indicators. ICT access provides an indication of the available information and communication technology infrastructure and individuals' access to primary ICT. The number of fixed telephone, mobile-cellular telephone and percentage of people who have a computer and access to the internet are monitored in this sector. The information and communication technology intensity and usage are measured in ICT use. The number of subscriptions in fixed broadband, mobile broadband and proportion of individuals using the internet are evaluated in this part. The education ratios of the population and skill for ICT are important for learning and using E-Commerce within ICT skill.

\subsubsection{E-Commerce diffusion}

The conditions and policy which are involved in developing digital resources are remarkable in the E-Commerce system development. The global environment, national environment and national policy are three main factors involved in broadening E-Commerce. The global environment, such as the production networks, rely heavily on ICT and E-Commerce to link supply chains in online businesses. Besides, the investment of international firms and global market competition are a drive to trade liberalization. In the national environment, the country demographics probably act as enablers for E-commerce growth. Also, the economic and financial resources including consumer preferences are first essential for motivating people to online business market in many countries. Important to the national policy are the liberalization of the telecommunications facilitates, ICT and internet diffusion. The industrial promotion in various forms such as the promotion of ICT and E-Commerce in online businesses is ensured by providing technical knowledge, training and funding for information technology literacy from the state. Especially, this is true with E-Commerce legislation on digital signatures, privacy, consumer protection, copyright and intellectual property. These factors impel the E-Commerce sustainably and efficiency.

The CMES paves the way to E-Commerce sustainability. The ICT and infrastructure will be developed through the national indicator standard for evaluating self-efficiency in the ICT sector. The sufficiency in digital resources and infrastructures that are efficiency and convenience will support the E-Commerce business to people throughout the supply chain. The income from the internal and external country online business will inevitably return to the country via taxation. This income will be used as investment for 
maintenance and development for the ICT and infrastructure in E-Commerce continually. The principles of E-Commerce taxation are the guidelines for evaluating the policy and regulation of E-Commerce tax in the light of CMES.

\section{Discussion and Findings}

This paper has various contributions regarding the relation of E-commerce taxation principles (ETP) on ICT development index (IDI) and E-Commerce diffusion (ED). Our results show the following contributions. Firstly, the findings of the study explain that the relationship between IDI and ED is both positive and significant. Secondly, the study illustrates that ED is positively related to ETP. Thirdly, the results of this study indicate that IDI has a direct impact on ETP. According to the study, ED and IDI have a direct effect on E-commerce taxation principle. Otherwise, it can be claimed that the effect of IDI on ETP is mediated through ED.

The IDI directly affected ED. The main factor in ICT access and ICT use is more important to promote E-Commerce growth via a sufficient digital resource [31, 32, 33, 34].

The high potential information and communication technology will be stimulating the national population to have the capability to access domestic high-speed internet network efficiently and conveniently. The developing digital resources which are necessary for the E-commerce system, for example, mobile devices, smartphone and communication public utility in high-speed internet network and public Wi-Fi broadband must improve continuously. Due to the necessity of digital resources, information technology, and communication system for E-commerce in the countries that have potential will have a competitive market advantage as well as framing trustworthy for the domestic and global entrepreneurs $[15,16,17]$. However, the result in ICT skill was a distinct finding. They thought that education was not important for the online business than their experiences.

Effectiveness and fairness (EF) and flexibility (FT) are more significant factors of E-commerce taxation principles (ETP). The factors of tax evasion, tax payable at the right time, including flexiblity in regulations and policy in tax E-Commerce must be considered in the online business continually [18, $19,20,21]$. While efficiency (EC) was not an influential factor in ETP, due to the cost in tax administration service it is not high in the current study.

The variables in Global Environment (GE), National Environment (NE) and National Policy (NP) were suitably significant and are related to 
E-Commerce Diffusion (ED) [14]. E-Commerce was affected by the global environment (GE) factor such as the global production network to supply the products cross over the country and trade liberalization for competition in the online market. In terms of National Environment (NE), the financial resources and demographics such as cultures and firm size are imperative for stimulating people to online business.

The findings showed results in the relationship between information and communication technology development and E-Commerce diffusion through E-Commerce taxation principles. Therefore, it should have a special type of tax for both domestic and international online trading entrepreneurs or E-Commerce entrepreneurs that bring in national income by using digital resources and information technology and every communication connection directly and indirectly. Therefore, particularly the tax should be paid for developing and maintaining digital resources and information technology infrastructure. The policies such as tax intensives or tax for investment should be promoted following this conceptual because it facilitates the development of technologies and knowledge from global investors to local businesses. The special tax will stimulate domestic and international entrepreneurs to have the capability to use information technology and communication system efficiently. Because, once the E-Commerce entrepreneurs and people become capable of accessing the efficient service rapidly, it will benefit E-Commerce operation precisely. Whether or not the information technology and communication system will be developing continuously and adequately, it will certainly lead to the profitable E-Commerce business and online trading correspondingly. On the other hand, online trading and E-Commerce growth will support the information technology and communication systems to expand. However, developing and promoting E-Commerce diffusion to grow needs accommodated regulation and a model with domestic and global conditions.

However, there were some limitations to this study. The useable questionnaires were sufficient merely to test the model but not sufficient to validate the model. Some items may be the bias from the experts in the process of IOC for validating the questionnaires. Furthermore, most of the respondents were from the online businesses in Thailand, therefore, the result may not be postulated to international online business. The community online commerce in Thailand may have some different regulation and demographics when compared with other developed countries such as the United States, China and the United Kingdom. Thus the results may not be generalized to some countries that would have more complex and different regulations and policy of E-Commerce taxation. In addition, there are still limitations with respect to 
other factors and data collection. The necessary elements should be included in the model for further studies such as the Information Systems Success Model in terms of the features of information quality, service quality, system quality, user satisfaction and intention to use [48].

\section{Conclusions}

The proposed framework from this study gives the perspective for guiding the policy for E-Commerce taxation through the concept of the CMES. According to the idea of the CMES, the concept is promoted and developed in the E-Commerce system growth. E-Commerce flow focuses on accessible and using information technology and communication systems of domestic and international businesses rapidly and conveniently. Because of the efficiency, E-Commerce accessibility will support E-Commerce advancement. Furthermore, CMES also evokes the factors which relate to the domestic and global conditions to be essential in E-Commerce development and hence collaborate to taxation appropriately. Consequently, E-Commerce enlargement will led to the principal in the national economic system, whereas the government will gain income and thus the national budget for E-Commerce taxation to develop digital resources and information technology structure for efficient and sustainable E-Commerce business can be prepared and submitted.

\section{References}

[1] OECD, 'Addressing the Tax Challenges of the Digital Economy, Action 1-2015', Final Report, OECD/G20 Base Erosion and Profit Shifting Project, OECD Publishing, Paris, 2015.

[2] Y. Xiang, Y. Ling, 'The Research on Chinese Taxation Policies Based on E-Commerce Model Classification', 2009 Second International Symposium on Electronic Commerce and Security. Vol. 1, pp. 431-434, 2009.

[3] E.W.T. Ngai, A. Gunasekaran, 'A review for mobile commerce research and applications', Decision Support Systems, Vol. 43, pp. 3-15, 2007.

[4] P. E. Kourouthanassis, G. M. Giaglis, 'Introduction to the Special Issue Mobile Commerce: The Past, Present, and Future of Mobile Commerce Research', International Journal of Electronic Commerce, Vol. 16(4), pp. 5-18, 2014. 
[5] M. Palil, 'The Effect of E-Commerce on Malaysian Tax System: An Empirical Evidence from Academicians and Malaysian Tax practitioner', Journal Akuntansi \& Keuangan, Vol. 6, No. 1, pp. 1-9, 2004.

[6] J. Chung, V. Chen, B. Sub, A. Widjaja, 'Facebook C2C social commerce: A study of online impulse buying', Decision Support Systems, Vol. 83, pp. 57-69, 2016.

[7] K. Laudon, C. Traver, 'E-Commerce 2016 business - technology society', Pearson Education Limited, twelfth Edition, 2016.

[8] Z. Huang, M. Benyoucef, 'From E-Commerce to social commerce: A close look at design features', Electronic Commerce Research and Applications, Vol. 12, pp. 246-259, 2013.

[9] Q. Yan, S. Wu, L. Wang, P. Wu, H. Chen, G. Wei, 'E-WOM from E-Commerce websites and social media: Which will consumers adopt?', Electronic Commerce Research and Applications, Vol. 17, pp. 62-73, 2016.

[10] D. Agrawal, W. Fox, 'Taxes in an E-Commerce generation', International Tax Public Finance, Vol. 24, pp. 903-926, 2017.

[11] R. Jones, S. Basu, 'Taxation of Electronic Commerce: A Developing Problem', International Review of Law, Computers \& Technology, Vol. 16, No. 1, pp. 35-52, 2010.

[12] A. Field, 'The proportion of Thai government revenue 2018', Retrieved June 25, 2018, Website: http://www.fpo.go.th.

[13] K. Kanungnij, 'Digital Economy Acceleration', The National Defense College of Thailand Journal, Vol. 59, No. 2, 2017.

[14] J. Gibbs, K. Kraemer, J. Dedrick, 'Environment and Policy Factors Shaping Global E-Commerce Diffusion: A Cross-Country Comparison', The Information Society, Vol. 19, pp. 5-18, 2003.

[15] K. Zhu, 'The Complementarity of Information Technology Infrastructure and E-Commerce Capability: A Resource-Based Assessment of Their Business Value', Journal of Management Information Systems, Vol. 21, No. 1, pp. 167-202, 2014.

[16] M. Choshin, A. Ghaffari, 'An investigation of the impact of effective factors on the success of E-Commerce in small- and mediumsized companies', Computers in Human Behavior, Vol. 66, pp. 67-74, 2016.

[17] A. Ayanso, D. Cho, K. Lertwachara, 'Information and Communications Technology Development and the Digital Divide: A Global and Regional Assessment', Information Technology for Development, Vol. 20, No. 1, pp. 60-77, 2013. 
[18] OECD, 'Electronic Commerce: Taxation Framework Conditions', A Report by the Committee on Fiscal Affairs, 1998.

[19] R. Azam, 'E-Commerce Taxation in China', Journal of Chinese Tax \& Policy, Vol. 3, Issue 1, pp. 10-20, 2013.

[20] Y. Pinanong, 'Internet Taxation', The Secretariat of the House of Representatives Thailand, 2018.

[21] Tax Policy Bureau, Fiscal Policy Office Thailand, 'Taxation in digital economy', Tax Policy Journal, Vol.55, Edition 1, 2015.

[22] S. Simon, 'Critical Success Factors for Electronic Services: Challenges for Developing Countries', Journal of Global Information Technology Management, Vol. 7(2), pp. 31-53, 2014.

[23] B. Yapara, S. Bayrakdara, M. Yaparb, 'The Role of Taxation Problems on the Development of Ecommerce', Procedia - Social and Behavioral Sciences, Vol. 195, pp. 642-648, 2015.

[24] C. Jing, 'Taxation of E-Commerce in China: applying US experience', International Conference on Social Science and Technology Education (ICSSTE 2015), pp. 663-665, 2015.

[25] C. Alley, D. Bentley, 'A remodelling of Adam Smith's tax design principles’ ,Faculty of Law at ePublications@bond, Bond University, 2005.

[26] R. Neumanna, J. Holmana, J. Almb, 'Globalization and tax policy', North American Journal of Economics and Finance, Vol. 20, pp. 193211, 2009.

[27] K. Kodchasila, 'Digital Economy Acceleration', The National Defence College of Thailand Journal, Vol. 59, No. 2, 2017.

[28] H. Gruber. (2019) 'Proposals for a digital industrial policy for Europe',Telecommunications Policy, Vol. 43, Issue 2, pp. 116-127, 2019.

[29] ICT Development Index, International Telecommunication Union, Geneva, Switzerland, pp. 22, 2009.

[30] K.H. Huarng, 'A comparative study to classify ICT developments by economies', Journal of Business Research, pp. 1174-1177, 2011.

[31] M. Dobrota, V. Jeremic, A. Markovic, 'A new perspective on the ICT Development Index', Information Development, Vol. 28 (4), pp. 271280, 2012.

[32] J. James, 'The ICT Development Index and the digital divide: How are they related?, Technological Forecasting \& Social Change, pp. 587-594, 2012. 
[33] A. Wilson1, U. David, E. Beatrice, O. Mary, 'How telecommunication development aids economic growth: Evidence from ITU, ICT development Index (IDI) top five countries for African region', International Journal of Business, Economics and Management, Vol. 1, No. 2, pp. 16-28, 2014.

[34] S. Malisuwan, D. Milindavanij, J. Sivaraks, N. Tiamnara, 'A Modified Model of ICT Development Index (IDI) for Thailand to Achieve the ICT Leader in Asian', International Journal of Advanced Research in Engineering and Technology, Vol. 6, Issue 12, pp. 39-48, 2015.

[35] A. Petrot'czi, E. Aidman, 'Measuring explicit attitude toward doping: Review of the psychometric properties of the Performance Enhancement Attitude Scale', Psychology of Sport and Exercise, Vol. 10, pp. 390-396, 2008.

[36] I. Yurdakul, H. Odabasi, K. Kilicer, A. Coklar, G. Birinci, A. Kurt, 'The development, validity and reliability of TPACK-deep: A technological pedagogical content knowledge scale', Computers \& Education, Vol. 58, pp. 964-977, 2012.

[37] J. Nunnally, H. Bernstein, 'Psychometric theory', New York: McGrawHill, 1994.

[38] R. Henson, J. Roberts, 'Use of exploratory factor analysis in published research common errors and some comment on improved practice', Educational and Psychological Measurement, Vol. 66(3), pp. 393-416, 2006.

[39] J. Pohlmann, 'Use and interpretation of factor analysis in The Journal of Educational Research'. The Journal of Educational Research, Vol. 98(1), pp. 14-23, 2004.

[40] M. Browne, R. Cudeck, 'Alternative ways of assessing model fit: Testing Structural Equation Models', pp. 136-162, 1993.

[41] J. Hair, W. Black, B. Babin, R. Anderson, 'Multivariate data analysis. Upper Saddle River', NJ: Prentice Hall, 2009.

[42] V. Sethi, M. S. Tandon, K. Dutta, 'A path model of antecedents of green purchase behaviour among Indian consumers', Int. J. Public Sector Performance Management, Vol. 4, No. 1, pp. 21-44, 2018.

[43] S. Omar, S. Jayasingam, R. A. Bakar, 'Does positive organisational behaviour and career commitment lead to work happiness?', Int. J. Business Excellence, Vol. 19, No. 1, pp. 44-64, 2019.

[44] S. Tanin, 'SPSS \& AMOS', Vol. 7, pp. 540-541, 2017. 
[45] R. Schumacker, R. Lomax, 'A beginner's guide to structural equation modelling (3rd Edition)', New Jersey: Lawrence Erlbaum Associates, 2010.

[46] W.G. Cochran, 'Sampling Techniques. 3rd Edition', John Wiley \& Sons, New York, 1997.

[47] I. K. Yurdakul, H. F. Odabasi, K. Kilicer, A. N. Coklar, G. Birinci, A. A. Kurt, The development, validity and reliability of TPACK-deep: A technological pedagogical content knowledge scale', Computers \& Education, Vol. 58, pp. 964-977, 2012.

[48] W. H. Delone, E. R. McLean, 'The DeLone and McLean Model of Information Systems Success:A Ten-Year Update', Journal of Management Information Systems, Vol. 19 (4), pp. 9-30, 2003.

\section{Biographies}

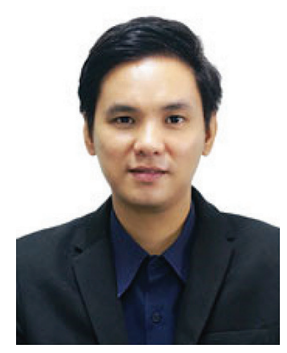

Somkeit Noamna received his B.Sc. degree in computer science from the Payap University, Thailand in 2003. He also received the M.Eng. degree in industrial engineering from the Chiang Mai University in 2013. He is currently the Lecturer of Modern Management Information Technology, College of Arts, Media and Technology, Chiang Mai University, Thailand. He is currently a Ph.D. student in Technology of Information System Management. His areas of research interests include information technology management, production management and computer for production management. 


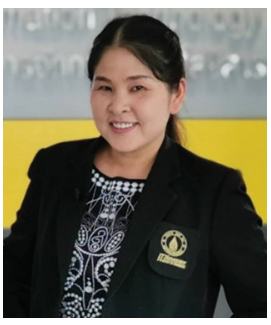

Supaporn Kiattisin received her B.Eng. degree in applied computer engineering from the Chiang Mai University, Chiang Mai, Thailand, in 1995, the M.Eng. degree in electrical engineering and the Ph.D. degree in electrical and computer engineering from the King Mongkut's University of Technology Thonburi, Bangkok, Thailand, in 1998, and 2006, respectively. She is currently the programme director of Technology of Information System Management Division, Faculty of Engineering, Mahidol University, Thailand. Her research interests include computer vision, image processing, robot vision, signal processing, pattern recognition, artificial intelligence, IoT, IT management, digital technologies, big data and enterprise architecture with TOGAF 9 certification. She is a member of the IEICE and TESA. She served as a Head of the IEEE Thailand Chapter in Biomedical Engineering. She also served as the Chairman of the TimesSOC Transaction Thailand. She has expertise in enterprise architecture (EA), data sciences, information technology in E-government and digital economy (DE). 